\title{
Optimization of Gas Turbine Maintenance Scheduling in PLN Tanjung Datuk Pekanbaru
}

\author{
Bambang Nofri, ${ }^{\text {* }}$ Anita Susilawati, ${ }^{\text {* }}$ and Romy ${ }^{\text {a }}$ \\ a) Mechanical Engineering Department, Universitas Riau, Indonesia \\ *Corresponding author: bambang.nofri@student.unri.ac.id, anitasusilawati@yahoo.com,romy@eng.unri.ac.id
}

\section{Paper History}

Received: 17-July-2020

Received in revised form: 29-September-2020

Accepted: 30-November-2020

\begin{abstract}
This study discusses determining the optimal scheduling for maintenance of gas turbine engines in PLN Tanjung Datuk Pekanbaru. The optimal maintenance scheduling is done on critical components, namely turbine blade and AVR (Automatic Voltage Regulator) using Monte Carlo simulation. The optimal scheduling maintenance scenario is done by generating random numbers from MTTF (Mean Time To Failure) and MTTR (Mean Time To Repair) values and data validity testing. The results of research for optimal checking of turbine engines are once every 10 days with the reliability of turbine engines $43 \%$. The optimal time for repairing a gas turbine in case of damage is 1.49 hours. The checking time for critical components of the turbine blade is 9 days and AVR of 12 days. The scenario of preventive maintenance can be set on periodically replacement of 117 days for turbine blade components and 173 days for AVR.
\end{abstract}

KEY WORDS: MTTF, Maintenance scheduling, Gas turbine, Turbine blade, AVR.

\subsection{INTRODUCTION}

A scheduling of machine maintenance is needed by the factory for the smooth production of a product [1]. Likewise in power plants, if there is no clear scheduling that can result in damage to the engine. Various methods are used by researchers to optimize engine maintenance [2-6], one way is to use Monte Carlo simulation. Monte Carlo simulation is a simulation of problem solving, by conducting random experiments [7,8]. According to
$[7,8]$ stated that Monte Carlo simulations derived from sampling statistics use random numbers and probabilities to solve problems by simulating the process directly. Therefore, the sampling taken randomly using Monte Carlo simulation is able to solve the problem of scheduling maintenance to be more optimal.

To minimize the damage that often occurs, it is necessary to have preventive maintenance. According [9] preventive maintenance is a maintenance activity that is carried out scheduled and generally done periodically. The periodic of preventive maintenance inspections to detect conditions can prevent engine conditions to break down and planned recovery from damage based on the results of the inspection. Preventive maintenance aims to improve reliability, prevent sudden engine damage, and can reduce engine downtime [10-12]. Random variables are used to determine reliability in the system. Distributions are often used in determining the level of reliability in a system such as normal distribution, weibull distribution, lognormal distribution and exponential distribution [13, 14].

Reliability is defined as the probability a machine or system perform certain functions within a given limit, under the given environment conditions, for a certain time [15]. The time needed for repairs starting from the damaging component until the repair and the machine is running again, that is called Mean Time to Repair (MTTR). The Mean Time To Failure (MTTF) means the average time of damage from the engine runs until the engine breaks down again. A optimizing of the preventive maintenance inspection intervals may increase the engine reliability [16]. The optimizing of maintenance schedule is affected the availability of the machine, which depends on its reliability and maintenance [17]. Furthermore, the scheduling of maintenance can support the effectiveness of the machine or system [18-20].

The objective of this paper is to conduct the optimization of gas turbine maintenance scheduling at PLN Tanjung Datuk Pekanbaru using Monte Carlo simulation. In research of Tuara et al. [21] discussed an improving gas turbine engine performance with "Implementation of Total Productive Maintenance (TPM) on Turbine Machine at PLN Tanjung Datuk Riau". However, they do not accomplish about scheduling for critical component of the gas turbine maintenance. Furthermore, this paper would continue 
their research by determine optimal scheduling for maintenance of turbine blade and AVR. It is expected to help maintain gas turbines machine to work in a continuous and stable manner. The scheduling is as well as structured maintenance such as preventive maintenance can thereby reducing non-productive time and reducing maintenance costs.

\subsection{RESEARCH METHOD}

The method in this paper is adopted the Monte Carlo simulation to optimal scheduling of maintenance of gas turbine engines in PLN Tanjung Datuk Pekanbaru. It can be performed by using a simple spreadsheet (Microsoft Excel). The construction of Monte Carlo simulation model is based on the problem obtained by historical data of an event and its frequency [22]:

$$
P i=f i / n
$$

Where:

$P i$ : Probability of occurrence $i$

$\mathrm{Fi}$ : Frequency of occurrence $i$

$n$ : Total frequency of all events.

The research flow can be seen in Figure 1.

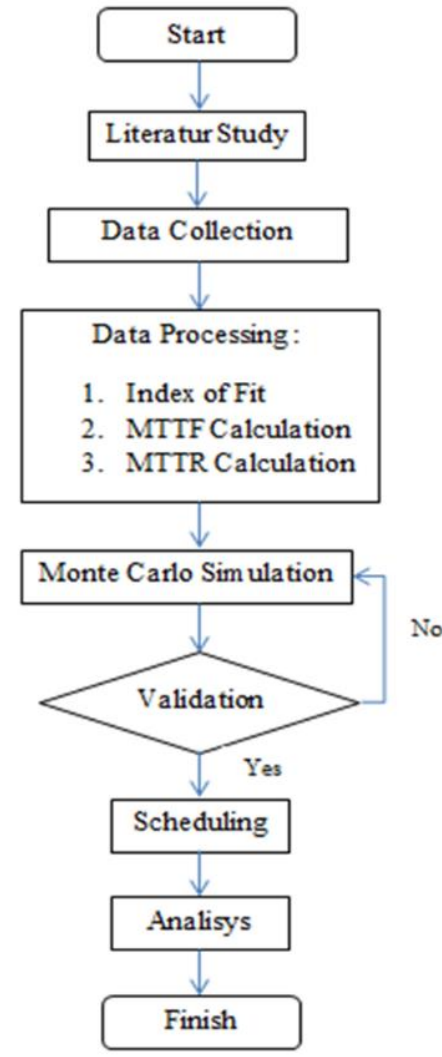

Figure 1: Research Flow Chart
The stages in the Monte Carlo simulation are as follows: (1) make a distribution of possibilities for important variables, (2) build a cumulative probability distribution for each variable in the first stage, (3) determine the random number interval for each variable, (4) make random numbers and (5) make a simulation of a series of experiments.

The TTR and TTF data obtained from the Monte Carlo simulation results were validated with the average similarity test and a statistical test using SPSS software. If the data obtained from the simulation results are in common with the actual data, then the TTR and TTF data can be used to determine maintenance scheduling. The scheduling obtained from simulation results is used to determine the scenarios that can be applied by companies to schedule turbine engine maintenance. So, it may reduce maintenance costs and optimize the maintenance system at PLN Tanjung Datuk Pekanbaru.

\subsection{RESULT AND DISCUSSION}

\subsection{Results}

Generation of turbine blade and AVR components maintenance scenarios is following steps:

a. A scheduling scenario is made for the maintenance of turbine blades and AVR according to the MTTF value of each component.

The turbine blade and AVR maintenance scenario can be seen in Table 1.

Table 1: Turbine Blade and AVR Maintenance Scenarios

\begin{tabular}{ccc}
\hline Component & Scenario (Time) & Scenario (Day) \\
\hline Turbine Blade & 1008,80 & 42 \\
AVR & 1688,17 & 70 \\
\hline
\end{tabular}

b. Random number generation of TTF and TTR for turbine Blades and AVR.

Random number generation aims to find out the values of a distribution in accordance with TTF and TTR data for each component. The generation of random numbers result is depicted in Table 2 for TTF, and Table 3 for TTR.

Table 2: The Random Number Generation Results of the TTF

\begin{tabular}{ccccccccc}
\hline No & $\begin{array}{c}\text { Turbin } \\
\text { Blade }\end{array}$ & AVR & No & $\begin{array}{l}\text { Turbin } \\
\text { Blade }\end{array}$ & AVR & No & $\begin{array}{c}\text { Turbin } \\
\text { Blade }\end{array}$ & AVR \\
\hline 1 & 432.25 & 1784.76 & 13 & 1208.32 & 415.01 & 44 & 1136.2 & 375.06 \\
2 & 871.02 & 402.17 & 14 & 2822.95 & 2948.72 & 45 & 415.36 & 721.53 \\
3 & 1777.31 & 805.65 & 15 & 1219.64 & 1149.01 & 46 & 1123.61 & 1363.53 \\
4 & 1349.4 & 4738.19 & 16 & 2788.41 & 2161.63 & 47 & 1094.67 & 2462.84 \\
5 & 1371.4 & 1824.55 & 17 & 1907.86 & 2056.79 & 48 & 2779.65 & 3413.86 \\
6 & 1310.42 & 683.64 & 18 & 1145.86 & 2098.93 & 49 & 836.48 & 4168.07 \\
7 & 1606.02 & 1576.59 & 19 & 213.55 & 2872.24 & 50 & 896.85 & 1587.61 \\
8 & 861.42 & 1420.32 & 20 & 1377.5 & 1268.85 & & & \\
9 & 1138.93 & 909.82 & $\ldots$. & $\ldots \ldots \ldots .$. & $\ldots \ldots \ldots .$. & & & \\
10 & 679.44 & 187.84 & 41 & 2139.25 & 1670.1 & & & \\
11 & 282.71 & 1678.12 & 42 & 808.12 & 3374.86 & & & \\
12 & 1411.35 & 345.46 & 43 & 1574.8 & 3210.64 & & & \\
\hline & & & & & & & &
\end{tabular}


Table 3: TTR Random Number Generation Results

\begin{tabular}{ccccccccc}
\hline No & $\begin{array}{c}\text { Turbin } \\
\text { Blade }\end{array}$ & AVR & No & $\begin{array}{c}\text { Turbin } \\
\text { Blade }\end{array}$ & AVR & No & $\begin{array}{c}\text { Turbin } \\
\text { Blade }\end{array}$ & AVR \\
\hline 1 & 0.91 & 2.06 & 13 & 1.16 & 1.89 & 44 & 0.37 & 1.08 \\
2 & 0.98 & 0.05 & 14 & 0.11 & 0.81 & 45 & 1.79 & 0.49 \\
3 & 0.91 & 1.42 & 15 & 0.1 & 2.15 & 46 & 3.31 & 0.15 \\
4 & 0.43 & 0.05 & 16 & 0.96 & 1.11 & 47 & 1.1 & 0.71 \\
5 & 1.57 & 4.02 & 17 & 0.36 & 0.49 & 48 & 0.38 & 0.48 \\
6 & 1.49 & 0.38 & 18 & 0.62 & 0.14 & 49 & 1.03 & 2.94 \\
7 & 1.2 & 3.97 & 19 & 1.93 & 2.31 & 50 & 0.08 & 0.4 \\
8 & 0.55 & 0.97 & 20 & 0.15 & 1.84 & & & \\
9 & 0.82 & 1.39 & $\ldots .$. & $\ldots \ldots$. & $\ldots \ldots$. & & & \\
10 & 0.83 & 1.53 & 41 & 0.66 & 0.29 & & & \\
11 & 0.86 & 0.08 & 42 & 2.56 & 1.22 & & & \\
12 & 1.33 & 1.21 & 43 & 0.58 & 0.83 & & & \\
\hline
\end{tabular}

c. Validation of turbine and AVR random number generation. The validity of the real data generation of TTF and TTR of random numbers turbine blade and AVR components were evaluated. To assess the validity of the two average similarity tests conducted on each component of the turbine blade and AVR.

- Turbine Blade Component

a. H0: Average TTF value of real system turbine component $=$ average of $\mathrm{TTF}$ value of turbine component from random number generation. H1: Average TTF value of real system turbine component is divided by the average of turbine TTF value resulting from random number generation.

b. Determination of $\alpha$ value and $t$ value of the table.

$$
\begin{aligned}
\alpha & =0.05 \\
d f & =4 \\
t & =43.03 \\
\text { t table } & =t \alpha(d f-2) \\
& =4.303
\end{aligned}
$$

c. Testing criteria

$H O$ is accepted if $-t$ table $\leq t$ arithmetic $<t$ table.

$H O$ is rejected if $t$ arithmetic $<-t$ table or $t$ arithmetic $>t$ table.

d. Statistic test

This statistic test was carried out using SPSS 16.0 software with the following results in Table 4-7.

Table 4: Turbine blade TTF Test Statistics

\begin{tabular}{clcc}
\hline Condition & Mean & N & Std Deviation \\
\hline Real & 924,80 & 4 & 847.71229 \\
Random & 1107,5 & 4 & 582.82256 \\
\hline
\end{tabular}

Table 5: Turbine blade TTR Test Statistics

\begin{tabular}{cccc}
\hline Condition & Mean & $\mathrm{N}$ & Std Deviation \\
\hline Real & 1.5450 & 4 & 0.97216 \\
Random & 0.8075 & 4 & 0.25382 \\
\hline
\end{tabular}

Table 6: TTF AVR Statistical Tests

\begin{tabular}{cccc}
\hline Condition & Mean & N & Std Deviation \\
\hline Real & 1549,1 & 5 & $1,081.66964$ \\
Random & 1842,7 & 5 & 2057.8792 \\
\hline
\end{tabular}

Table 7: TTR AVR Test Statistics

\begin{tabular}{cccc}
\hline Condition & Mean & $\mathrm{N}$ & Std Deviation \\
\hline Real & 1.65 & 5 & 0.93941 \\
Random & 1.52 & 5 & 1.6874 \\
\hline
\end{tabular}

e. Statistical result

The test results using SPSS 16.0 software was obtained the $-\mathrm{T}$ table $\leq \mathrm{T}$ count $<\mathrm{T}$ table $(-4.303 \leq-1.249<4.303)$, then it can be concluded that $\mathrm{H} 0$ was accepted, that is the average TTF of the turbine blade real component equal to the average of TTF values of the turbine blade component of a random number generation.

Recapitulation of average test results for TTF and TTR data's turbine blade and AVR components with real conditions and the generation of random numbers using SPSS 16.0 can be seen in Table 8 and Table 9.

Table 8: Recapitulation of Test Validity of TTF Data for Random and Real Numbers

\begin{tabular}{ccccc}
\hline No & Component & T count & T table & Result \\
\hline 1 & Turbine Blade & -1.249 & 4.303 & Accept H0 \\
2 & AVR & -0.232 & 3.18 & Accept H0 \\
\hline
\end{tabular}

Table 9: Recapitulation of Test Validity of Random and Real TTR Data Numbers

\begin{tabular}{ccccc}
\hline No & Component & T count & T table & Result \\
\hline 1 & Turbine Blade & $-1,249$ & 4.303 & Accept H0 \\
2 & AVR & 0,180 & 3.18 & Accept H0 \\
\hline
\end{tabular}

In Table 8 and Table 9, it is known that the average TTF and TTR data from the random number results were the same as the average TTF and TTR data from real conditions.

- Scheduling Optimization

The proposed scheduling optimization for turbine blade and AVR components is aimed at carrying out routine maintenance to anticipate failures that would be occurred. Recapitulation of inspection scheduling is shown in Table 10. The checking for scheduling improvement of the components can be seen in Table 11 .

Table 10: Recapitulation of Inspection Scheduling Simulation Results

\begin{tabular}{lcc}
\hline Component & Checking (Time) & Checking (Day) \\
\hline Turbine Blade & 213.55 & 9 \\
AVR & 291.56 & 12 \\
\hline
\end{tabular}

Table 11: Recapitulation of Simulation Results for Scheduling Improvements

\begin{tabular}{lcc}
\hline Component & Repair (Time) & Repair (Day) \\
\hline Turbine Blade & 2822.95 & 117 \\
AVR & 4168.07 & 173 \\
\hline
\end{tabular}




\subsection{Discussion}

The calculation of MTTF and MTTR function to optimize the failure and repair time of a gas turbine or component can work properly. The MTTF and MTTR are also used as a reference for scheduling maintenance of a machine and components.

From the data of damage and repair of gas turbines data in real field was occurred 7 (seven) times of maintenance carried out from January 2018 to September 2019. After calculating the index of fit $(r)$ value or the reliability of the turbine engine with the 4 distributions approach, it was obtained:

$$
\begin{array}{ll}
r \text { weibull } & =0,2524 \\
r \text { normal } & =0,4314 \text { (the biggest) } \\
r \text { eksponensial } & =0,3998 \\
r \text { lognormal } & =0,2962
\end{array}
$$

The highest reliability value using the normal distribution with a value of $0.43 \times 100 \%=43 \%$. Then it is selected at the optimum condition ( $43 \%$ of the reliability) to analyzed the MTTF turbine engine time span needs to be maintained. The MTTF of gas turbine was obtained 230.53 hours $=9.61$ days (rounded up to 10 days). The time span of improvement that occurs in real field is minimum 35.17 hours $=1.6$ days (rounded up to 2 days) and a maximum of $505.84=21.07$ days (rounded up to 21 days). For optimal schedule in the future checking of the gas turbine engine is once every 10 days with the reliability of the turbine engine $43 \%$.

After obtaining an optimal time span of checking the turbine engine by 10 days, the repair time was analyzed in case of damage to the turbine engine. While, the average turbine engine repair time was 1.49 hours. The actual repair time took place in the field of 1.00 hours and a maximum of 3.05 hours. Therefore, the optimal time for repairing a gas turbine in case of damage was 1.49 hours.

The generation of random numbers simulation that aims to produce values that have an equivalent distribution with TTF data and TTR critical components were showed in Figure 2 and 3, respectively.

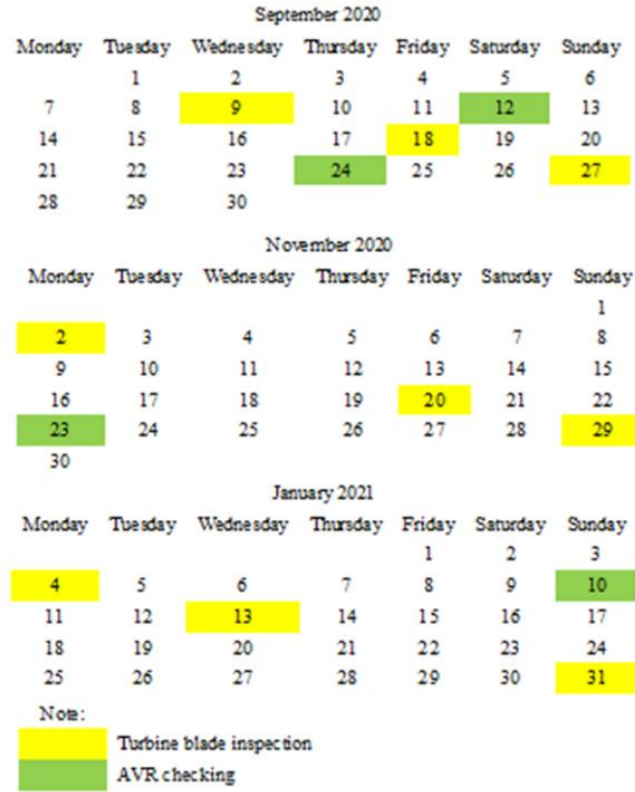

Figure 5: The Proposed Schedule of Preventive Maintenance for Turbine Blade and AVR
TTF random numbergeneration

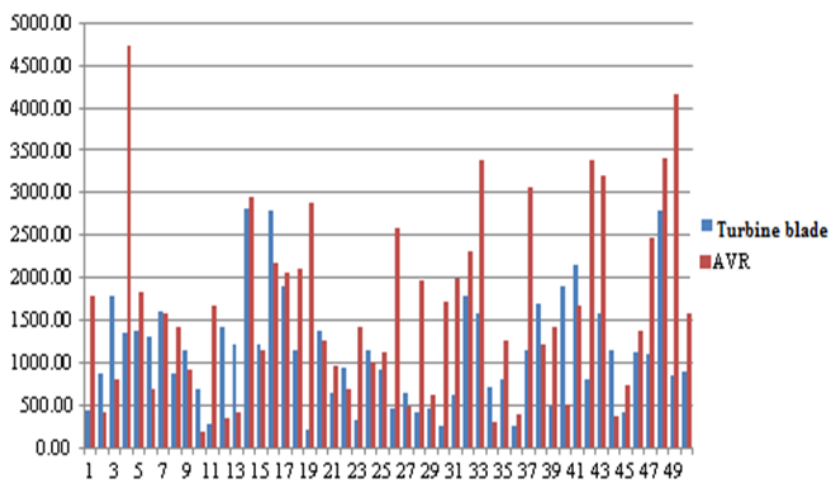

Figure 2: The TTF Random Number Generation Graph TTRrandom numbergeneration

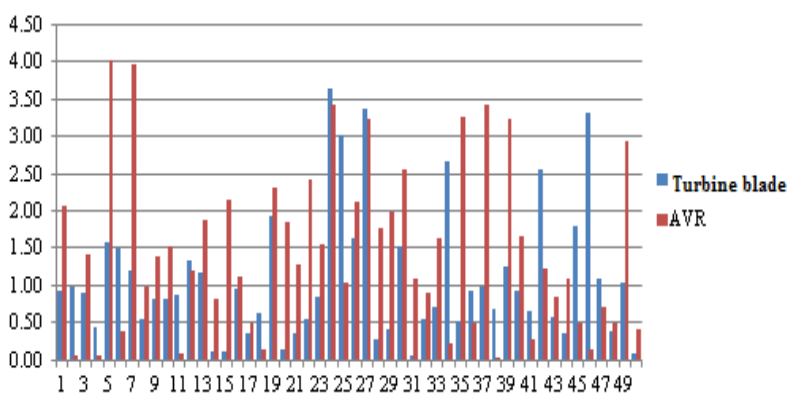

Figure 3: The TTR Random Number Generation Graph

The time span of checking critical components of a gas turbine engine is turbine blades of 213.55 hours $=9$ days and AVR of 291.56 hours $=12$ days. Therefore, based the simulation results can be provided a proposed schedule within a 6 months trial period from September 2020 - February 2021, as is depicted in Figure 4.
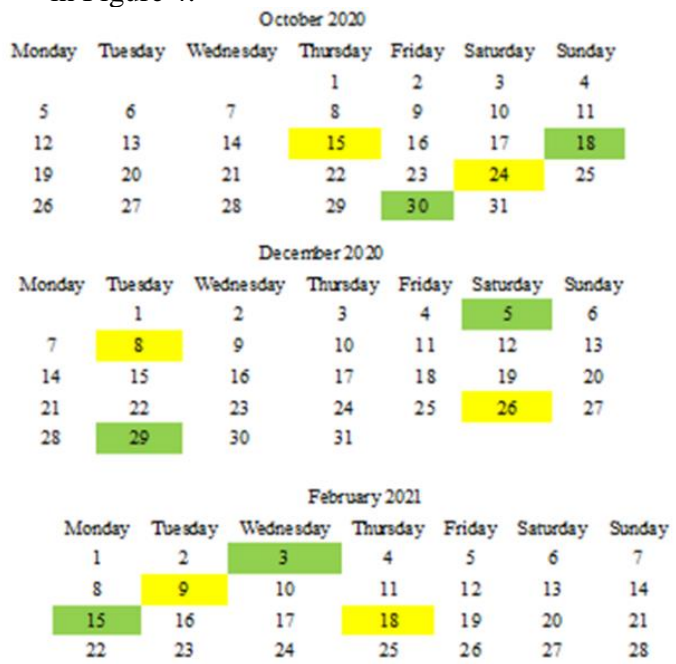


\subsection{CONCLUSION}

There are two critical components of the gas turbine engine, which be determined in the maintenance time scheduling optimizing, is the turbine blade and AVR. The optimal checks and repairs on turbine blades components are every 9 days inspection and every 117 days checking for repairs them. Whereas the AVR component is every 12 days inspection and every 173 days for checking repairs. As for checking the optimal gas turbine engine is done every 10 days. Furthermore, the propose result a merging of the schedule for checking the gas turbine engine and critical components of the turbine blade and AVR every 10 days. Therefore, it can save time and maintenance costs. It would be recommendation to pay more attention in maintaining critical components. So, they do not affect other components, if a component is damaged and fails. The calculation and analysis of gas turbine engine maintenance costs can be carried out for further research.

\section{ACKNOWLEDGEMENTS}

The author acknowledges the management and field staff of Section of Mechanics, Operators and Instrumentation in the PLN Tanjung Datuk, Pekanbaru, Riau, Indonesia for supports these research activities.

\section{REFERENCE}

[1]. Wang, L., Chu, J. and Mao, W. (2008). An optimum condition-based replacement and spare provisioning policy based on Markov chains, Journal of Quality in Maintenance Engineering, Vol. 14, No. 4, pp: 387-401.

[2]. Gupta, A. and Lawsirirat, C. (2006). Strategically optimum maintenance of monitoring enabled multicomponent systems using continuous-time jump deterioration models, Journal of Quality in Maintenance Engineering, Vol. 12, No. 3, pp: 306-329.

[3]. Marquez, A.C and Heguedas, A.S. (2002). Models for maintenance optimization: A study for repairable systems and finite time periods, Reliability Engineering and System Safety, Vol. 75, No. 3, pp: 367-377.

[4]. Nicolai, R. P. and Dekker, R. (2008). Optimal maintenance of multi-component systems: a review, in Kobbacy, K. and Murthy, D. N. (eds.) Complex system maintenance handbook, Springer, London, pp. 263-286.

[5]. Briš, R. (2008). Parallel simulation algorithm for maintenance optimization based on directed Acyclic Graph, Reliability Engineering and System Safety, Vol. 93, No. 6, pp: 874-884.

[6]. Sharma, A., Yadava, G. and Deshmukh, S. (2011). A literature review and future perspectives on maintenance optimization, Journal of Quality in Maintenance Engineering, Vol. 17, No. 1, pp: 5-25.

[7]. Marseguerra, M., Zio, E. and Podofillini, L. (2002). Condition-based maintenance optimization by means of genetic algorithms and Monte Carlo simulation, Reliability Engineering and System Safety, Vol. 77, No. 2, pp: 151-165.
[8]. Yeh, T.M. and Sun, J.J. (2011). Preventive maintenance model with FMEA and monte carlo simulation for the key equipment in semiconductor foundries, Scientific Research and Essays, Vol. 6, No. 26, pp: 5534-5547.

[9]. Arab, A., Ismail, N. and Lee, L.S. (2013). Maintenance scheduling incorporating dynamics of production system and real-time information from workstations, Journal of Intelligent Manufacturing, Vol. 24, No. 4, pp: 695-695.

[10]. Lynch, P., Adendorff, K., Yadavalli, V.S.S. and Adetunji, O. (2013). Optimal spares and preventive maintenance frequencies for constrained industrial systems, Computers and Industrial Engineering, Vol. 65, No. 3, pp: 378-387.

[11]. Peng, Y., Dong M. And Zuo, M.J. (2010), Current status of machine prognostics in condition-based maintenance: $a$ review, International Journal of Advanced Manufacturing Technology, Vol. 50, pp: 297-313.

[12]. Jong, H.S. and Hong, B.J. (2015). On condition based maintenance policy, Journal of Computational Design and Engineering, Vol. 2, No. 2, pp: 119-127, https://doi.org/10.1016/j.jcde.2014.12.006.

[13]. Beaurepaire, P., Valdebenito, M.A., Schuëller, G.I. and Jensen, H.A. (2012). Reliability-based optimization of maintenance scheduling of mechanical components under fatigue, Computer Methods in Applied Mechanics and Engineering, Vol. 221-222, pp: 24-40.

[14]. Valdebenito, M.A. and Schuëller, G.I. (2010). Design of maintenance schedules for fatigue-prone metallic components using reliability-based optimization, Computer Methods in Applied Mechanics and Engineering, Vol. 199, No. 33-36, pp: 2305-2318.

[15]. Kiran, D.R. (2017). Reliability Engineering in Total Quality Management, Butterworth-Heinemann, Chapter 27, pp: 391-404, doi.org/10.1016/B978-0-12-811035.

[16]. Wu, S., Chen, L., Wu, Q. and Wang, Z. (2015). Linking component importance to optimisation of preventive maintenance policy, Reliability Engineering and System Safety. Vol. 146. 10.1016/j.ress.2015.10.008.

[17]. Candra, N.C, Susilawati, A, Herisiswanto and Setiady, W. (2017). Implementation of Total Productive Maintenance (TPM) to Improve Sheeter Machine Performance, MATEC Web Conf., Vol. 135, 00028, https://doi.org/10.1051/matecconf/201713500028.

[18]. Kim, J., Lee S. and Shin, H. 2013. Effective Task Scheduling for Embedded Systems Using Iterative Cluster Slack Optimization, Circuits and Systems, Vol. 4 No. 8, pp.: 479-488. doi: 10.4236/cs.2013.48063.

[19]. Hong, S., Li, H., and Wang, F. (2013). Maintenance Scheduling of Distribution System with Optimal Economy and Reability, Engineering, Vol. 5, pp: 14-18.

[20]. Hariyanto, B and Romy (2020). Maintenance Schedule Optimization for Turnaround Hot Gas Path Inspection of Gas Turbine in North Duri Cogeneration Plant Using Impact Method, Journal of Ocean, Mechanical and Aerospace -Science and Engineering, Vol. 64, No. 1, pp:25-33.

[21]. Tuara, M.R., Susilawati, A and Romy (2017). Implementasi Total Productive Maintenance (TPM) pada Mesin Turbin di PLN Tanjung Datuk Riau. JOM Fakultas Teknik, Vol.5, No. 2. 
[22]. Mardiansyah, R.F. (2018). Analisa Ekonomis Peralatan Pulverizer Untuk Optimalisasi Keandalan PLTU Dengan Simulasi Monte Carlo Dan Pendekatan Analisa Biaya Siklus Hidup (Studi Kasus: PLTU Rembang). Tesis. Program Pascasarjana Megister Teknik Industri Universitas Islam Indonesia. 